\title{
Upregulated IGF-1 in the lungs of asthmatic mice originates from alveolar macrophages
}

\author{
JING HE $^{1 *}$, MIMI MU ${ }^{1 *}$, HELONG WANG $^{1}$, HUA MA $^{1}$, XU TANG $^{2}$, QIANG FANG $^{3}$, \\ SHUJUN GUO ${ }^{1}$ and CHUANWANG SONG ${ }^{1}$ \\ ${ }^{1}$ Department of Immunology, Anhui Provincial Key Laboratory of Infection and Immunity; \\ Departments of ${ }^{2}$ Clinical Laboratory of Medicine, and ${ }^{3}$ Microbiology and Parasitology, \\ Bengbu Medical College, Bengbu, Anhui 233030, P.R. China
}

Received March 7, 2018; Accepted November 2, 2018

DOI: $10.3892 / \mathrm{mmr} .2018 .9726$

\begin{abstract}
Asthma is characterized by inflammation and remodeling of the airways. Insulin-like growth factor-1 (IGF-1) serves an important role in the repair of lung tissue injury and airway remodeling by elevating collagen and elastin content, increasing the thickness of smooth muscle and promoting the proliferation of lung epithelial and interstitial cells, as well as fibroblasts; however, the content of IGF-1 and its cellular origin in the lungs of patients with asthma remain unknown. In the present study, a mouse model of asthma was constructed. Following isolation of alveolar macrophages (AMs), the content of IGF-1 in lung tissue and bronchoalveolar lavage fluid (BALF) was detected by ELISA. The proliferation and phagocytosis of alveolar epithelial cells (AECs) stimulated by IGF-1 were detected by Cell Counting Kit- 8 method and flow cytometry, respectively. In the present study, IGF-1 was upregulated in the lung tissues of asthmatic mice, and the content of IGF-1 in BALF was also elevated. Depletion of AMs by treating mice with 2-chloroadenosine via nose dripping reversed the increase of IGF-1 by $80 \%$ in lung tissues and by $\sim 100 \%$ in BALF of asthmatic mice, suggesting that elevated IGF-1 in asthmatic mice predominantly originated from AMs. As IGF-1 promotes the proliferation and phagocytosis of AECs, AM-derived IGF-1 may serve an important role in the regulation of airway inflammation and remodeling in asthmatic mice.
\end{abstract}

Correspondence to: Dr Chuanwang Song, Department of Immunology, Anhui Provincial Key Laboratory of Infection and Immunity, Bengbu Medical College, 2600 Donghai Avenue, Bengbu, Anhui 233030, P.R. China

E-mail: chuanwangsong@163.com

*Contributed equally

Key words: insulin-like growth factor 1, alveolar epithelial cell, alveolar macrophage

\section{Introduction}

Asthma is one of the most common types of respiratory diseases; $\sim 300,000,000$ asthma cases are reported worldwide and 250,000 people succumb to mortality from this disease annually (1). An epidemiological study revealed that the incidence and mortality of asthma have increased in the past decade, and has become a global public health problem (2). Asthma is a chronic inflammatory disease involving numerous cells and cytokines, and is characterized by inflammation and hyper-responsiveness of the airway (3). Recurrent airway inflammation results in inflammatory injury and fibrotic proliferation of the airway epithelium, consequently stimulating airway remodeling (4), which is also an important feature of asthma.

Insulin-likegrowth factor-1(IGF-1)is ametabolism-associated growth factor that is structurally and functionally similar to insulin (5). IGF-1 serves an important regulatory role in the proliferation, differentiation, metabolism and survival of cells (6). IGF-1 is predominantly synthesized and secreted in the liver; additionally, IGF-1 is also produced by other tissues, such as the lungs, where it functions as an autocrine and paracrine hormone (7). In addition, IGF-1 exhibits numerous biological functions in a variety of organs, and it is associated with the pathogenesis of various diseases (8). IGF-1 stimulates the proliferation of lung epithelial cells and serves an important role in tissue repair in response to lung injury (9). Furthermore, IGF-1 promotes the proliferation of pulmonary fibroblasts via the IGF-1 receptor-mediated upregulation of FOS proto-oncogene activator protein 1 transcription factor subunit, early growth response protein (EGR)1 and EGR2 (10). IGF-1 can also stimulate the differentiation of fibroblasts into myoblast cells and serves an important role in pulmonary fibrosis (11). Chetty and Nielsen (12) reported that hyperoxia-induced IGF-1 promoted the proliferation of pulmonary interstitial cells, indicating that IGF-1 signaling may be involved in the repair of hyperoxia-induced lung injury. Vieira et al (13) revealed that creatine supplementation aggravated airway remodeling by increasing the thickness of smooth muscle, and upregulating the expression levels of collagen and elastin in the airway via IGF-1. Therefore, IGF-1 is associated with tissue repair and airway remodeling in the lungs; however, the cellular origin of IGF-1 in asthma remains unknown. 
In the present study, the levels of IGF-1 in the lung tissues and bronchoalveolar lavage fluid (BALF) of asthmatic mice, as well as its cellular origin were examined. In addition, whether IGF-1 affected the proliferation and phagocytosis of alveolar epithelial cells (AECs) was investigated.

\section{Materials and methods}

Preparation of the asthma model. Female BALB/c mice (6-weeks-old) were purchased from the Animal Center of Bengbu Medical College. The mice (18-20 g) were housed in specific pathogen-free grade conditions under a $12 \mathrm{~h}$ light-dark cycle at $20-26^{\circ} \mathrm{C}$ with free to access food and water. BALB/c mice were sensitized by an intraperitoneal injection of $200 \mu \mathrm{l}$ sensitizing solution [50 $\mu \mathrm{g}$ ovalbumin (OVA) and $2 \mathrm{mg}$ $\mathrm{Al}(\mathrm{OH})_{3}$ ] on days 0,7 and 14 . Sensitized mice were challenged by the administration of aerosolized 5\% OVA solution from day 21 , with 30 min of atomization every day and continuous atomization for 5 weeks. Control mice received a mock challenge with PBS. The present study was approved by the Ethics Committee of the Bengbu Medical College (Bengbu, China).

Preparation of BALF and acquisition of alveolar macrophages $(A M)$. Mice were placed in a supine position following anesthesia with an intraperitoneal injection of chloral hydrate (400 mg/kg), and tracheal intubation was performed using a $12^{\#}$ needle. Mice underwent lavage using $0.8 \mathrm{ml}$ saline via intubation for a total of 6 times. BALF was isolated by centrifugation at $1,230 \mathrm{x} \mathrm{g}$ for $5 \mathrm{~min}$ at $4^{\circ} \mathrm{C}$, and the supernatant was stored at $-70^{\circ} \mathrm{C}$ prior to cytokine analysis. Following erythrocyte lysis using Red Blood Cell Lysis Buffer (Beyotime Institute of Biotechnology, Shanghai, China), the pellet was resuspended in RPMI-1640 complete medium (containing 10\% fetal bovine serum, HyClone; GE Healthcare Life Sciences, Logan, UT, USA) and then seeded in a 6 -well plate followed by incubation at $37^{\circ} \mathrm{C}$ for $2 \mathrm{~h}$. The adherent cells were identified as AMs and the purity of macrophages was determined to be $>95 \%$.

AM depletion. AM depletion was performed as described previously (14). Briefly, sensitized mice were treated with 2-chloroadenosine (2-CA; Sigma-Aldrich; Merck KGaA, Darmstadt, Germany) via the nose one day prior to atomization. Each mouse received $10 \mu \mathrm{g} 2-\mathrm{CA}$ in $20 \mu \mathrm{l}$ PBS, once every 3 days until the 54th day of the experimental process. Asthma model mice received PBS instead of 2-CA as the control. After obtaining the bronchoalveolar lavage, slides were prepared and stained with Wright-Giemsa staining solution. Specifically, 95\% ethanol $(1 \mathrm{ml})$ was added to each sample and cells were fixed for $10 \mathrm{~min}$ at room temperature. The ethanol was removed and Wright-Giemsa staining solution was added. The cells were stained for $5 \mathrm{~min}$ at $25^{\circ} \mathrm{C}$; the staining solution was discarded, the cells were rinsed with water and observed using a IX71 light microscope (magnification, x400; Olympus Corporation, Tokyo, Japan). Differential cells counts were performed and at least 400 cells were counted per sample. Post-treatment assessment by cell counting revealed that $75 \%$ of AMs were depleted, whereas the other cells in BALF were not affected.

Enzyme-linked immune sorbent assay (ELISA). The mice were sacrificed and the lung homogenate supernatant and
BALF were collected. The levels of IGF-1 in the BALF and supernatant were determined using an ELISA kit (cat. no. CSB-E04581m; CUSABIO, Wuhan, China) according to the manufacturer's protocols.

Cell proliferation assay. Alveolar epithelial cells (MLE-12; Jining Shiye Biotechnology Co., Ltd., Shanghai, China) in complete Dulbecco's modified Eagle's medium (containing $10 \%$ fetal bovine serum, HyClone; GE Healthcare Life Sciences) were seeded on 12-well plates and cultured to 70-80\% confluence at $37^{\circ} \mathrm{C}$ prior to stimulation using IGF-1 $(10 \mathrm{ng} / \mathrm{ml})$ the following day. Cells were divided into the control group and IGF-1-stimulated group. Following stimulation with IGF-1 for $12,24,48,72$ and $96 \mathrm{~h}$ at $37^{\circ} \mathrm{C}, 3 \times 10^{3}$ MLE-12 cells were seeded on 96-well plates. Then, $10 \mu \mathrm{l}$ Cell Counting Kit-8 (CCK-8; Beyotime Institute of Biotechnology) reagent was added into each well followed by incubation at $37^{\circ} \mathrm{C}$ for $2 \mathrm{~h}$. The absorbance at $450 \mathrm{~nm}$ was measured using a microplate reader.

Flow cytometry. MLE-12 cells were stimulated using $50 \mathrm{ng} / \mathrm{ml}$ IGF-1 (Abcam, Cambridge, UK) for $48 \mathrm{~h}$ at $37^{\circ} \mathrm{C}$, treated with $1 \mu 1$ YELLOW GREEN (YG; excitation=441 $\mathrm{nm}$ and emission=486) fluorescent microspheres (1 $\mu \mathrm{m}$ in diameter, Polysciences, Inc., Warrington, PA, USA), and then incubated at $37^{\circ} \mathrm{C}$ for $2 \mathrm{~h}$. The control was treated with medium only. MLE-12 cells were washed twice using phosphate buffer and fixed for $30 \mathrm{~min}$ using $1 \%$ paraformaldehyde at $4^{\circ} \mathrm{C}$. Then, cell phagocytosis of fluorescent microspheres was detected using a FACSCalibur flow cytometer (BD Biosciences, Franklin Lakes, NJ, CA, USA). MLE-12 cells with fluorescent signals were analyzed using FlowJo 7.6.1 (FlowJo LLC, Ashland, OR, USA).

Western blot analysis. Total protein was extracted from lung tissue homogenates of mice using NP-40 Lysis Buffer (Beyotime Institute of Biotechnology). Extracted protein concentrations were measured using a Bicinchoninich Acid protein assay kit (Beyotime Institute of Biotechnology); $30 \mu \mathrm{g}$ protein were separated by $10 \%$ SDS-PAGE and transferred to nitrocellulose membranes. Then the membranes were blocked using 5\% milk at room temperature for $2 \mathrm{~h}$ and incubated using the primary antibodies against IGF-1 (1:1,000; cat. no. ab9572; Abcam) or $\beta$-actin $(1: 1,000$; cat. no. AF0003; Beyotime Institute of Biotechnology) at $4{ }^{\circ} \mathrm{C}$ overnight. Membranes were washed in Tris-buffered saline with $0.05 \%$ Tween-20 and incubated with horseradish peroxidase-labeled Goat Anti-Rabbit IgG (1:1,000; cat. no. A0208; Beyotime Institute of Biotechnology) at room temperature for $2 \mathrm{~h}$. The bands were visualized using an enhanced chemiluminescence kit (Beyotime Institute of Biotechnology). Relative protein expression was determined by densitometric analysis using Image Lab 4.1 (Bio-Rad Laboratories, Hercules, CA, USA). $\beta$-actin was used as the reference protein and the experiment was conducted three times.

Statistical analysis. The data were presented as mean \pm standard deviation. Statistical comparison between two groups was performed using a Student's t-test. Comparisons between multiple groups were performed using a one-way analysis of variance followed by a Least Significant Difference post hoc 

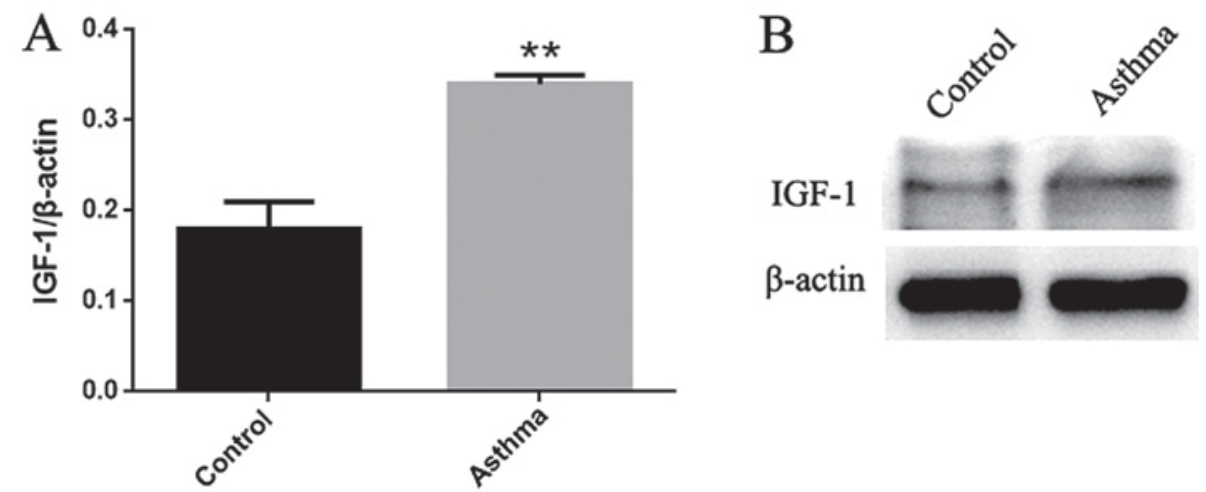

Figure 1. Elevated expression levels of IGF-1 in the lung tissues of asthmatic mice. Expression levels of IGF-1 in the lung tissue of asthmatic and control mice were determined by western blotting. (A) Densitometric analysis of blots from three independent experiments. (B) Representative western blotting from the triplicates. ${ }^{* *} \mathrm{P}<0.01$ vs. the control group. IGF-1, insulin-like growth factor 1 .

test. All experiments were repeated at least three times. $\mathrm{P}<0.05$ was considered to indicate a statistically significant difference.

\section{Results}

Expression levels of IGF-1 in lung tissues and BALF are increased in asthmatic mice. A mouse model of allergic asthma was constructed as described previously (14). In asthmatic mice, the number of eosinophils in BALF was increased and the expression levels of Th1 cytokine interferon- $\gamma$ was decreased, while those of Th2 cytokines interleukin-4 (IL-4) and IL-13 were increased $(15,16)$. The expression levels of IGF-1 in the lung tissues were significantly upregulated in asthmatic mice compared with in normal mice (Fig. 1). In addition, the expression levels of IGF-1 in BALF were significantly increased in asthmatic mice compared with in normal mice $(\mathrm{P}<0.01$; Fig. 2$)$.

Elevated IGF-1 in the lungs of asthmatic mice predominantly originates from AMs. As 2-CA effectively depletes AMs (17), it was applied as nasal drops to deplete AMs in the present study. Treatment with 2-CA depleted $75 \%$ of AMs and significantly reversed the increase in IGF-1 by $\sim 100 \%$ in the BALF $(\mathrm{P}<0.01)$ and $85 \%$ in lung tissues of asthmatic mice $(\mathrm{P}<0.01$; Fig. 3). This indicated that AMs are the main source of IGF-1 in the airways.

IGF-1 promotes the proliferation of AECs. IGF-1 can regulate the proliferation of numerous types of cell (9). As AMs are in close proximity to AECs in the alveolar microenvironment, whether AM-derived IGF-1 affects the proliferation of AECs was investigated in the present study. MLE-12 cells were stimulated with IGF-1 (10 ng/ml), and cell proliferation was determined using the CCK-8 method. As presented in Fig. 4, the optical density in IGF-1 stimulated groups at 24, 48, 72 and $96 \mathrm{~h}$ was significantly increased compared with in the respective controls $(\mathrm{P}<0.01)$, indicating that $\mathrm{IGF}-1$ promoted the proliferation of AECs.

IGF-1 promotes the phagocytosis of AECs. IGF-1 signaling is involved in the inflammatory response (18); the role of non-professional phagocytosis in the inflammatory response has been reported (19). Thus, whether IGF-1 affects the phagocytosis of AECs, non-professional phagocytes, was

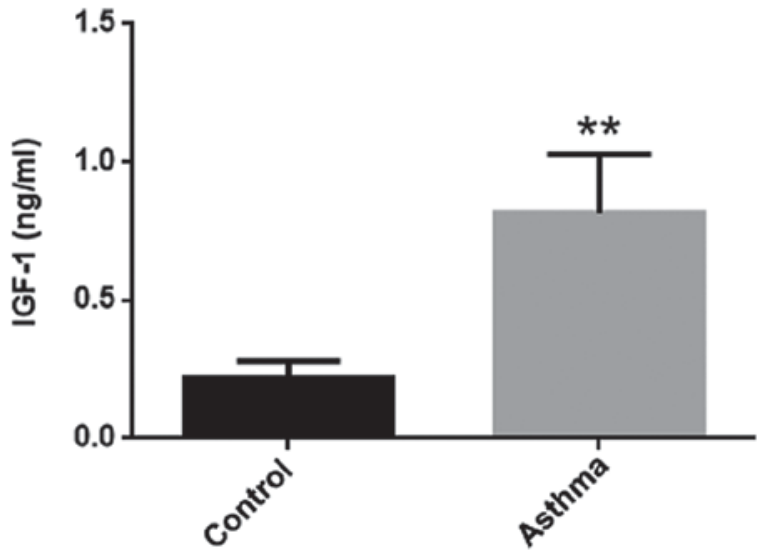

Figure 2. Expression levels of IGF-1 are increased in the BALF of asthmatic mice. Expression levels of IGF-1 in the BALF of asthma and control mice were determined by ELISA. IGF-1 was significantly upregulated in the BALF of asthmatic mice compared with in normal mice. ${ }^{* *} \mathrm{P}<0.01$ vs. the control group. BALF, bronchoalveolar lavage fluid; IGF-1, insulin-like growth factor 1 .

investigated in the present study. Stimulation of MLE-12 cells with IGF-1 $(50 \mathrm{ng} / \mathrm{ml})$ significantly increased the digestion of fluorescent microspheres compared with the control $(\mathrm{P}<0.01$; Fig. 5). This suggested that IGF-1 may inhibit airway inflammation by promoting the phagocytosis of AECs.

\section{Discussion}

In the present study, the IGF-1 content in lung tissues and BALF of asthmatic mice was significantly increased, and elevated IGF-1 was predominantly derived from AMs. IGF-1 serves an important role in the development of normal lung tissue and is also associated with the pathology of numerous lung diseases (20). For example, patients with systemic sclerosis, severe skin lesions and pulmonary fibrosis exhibited increased serum levels of IGF-1, and the mRNA levels of IGF-1 in the skin of these patients were notably elevated compared with in normal controls (21). In a model of bleomycin-induced pulmonary fibrosis, the expression levels of IGF-1 in lung tissues were increased by 3-4-fold compared with in the control group (22). In addition, IGF-1 was upregulated in the lung tissue of acute respiratory distress syndrome (ARDS) patients with fibrous 
A

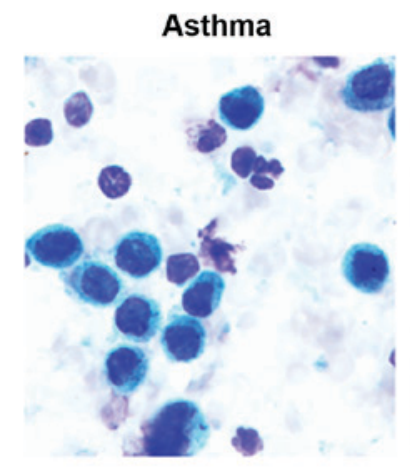

B

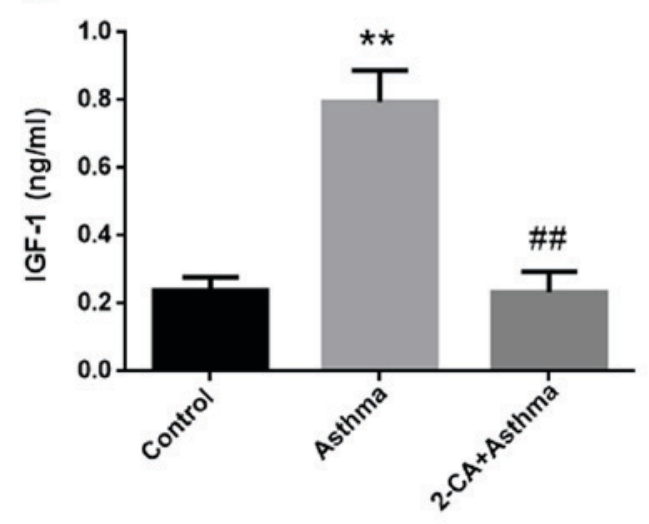

2-CA + Asthma

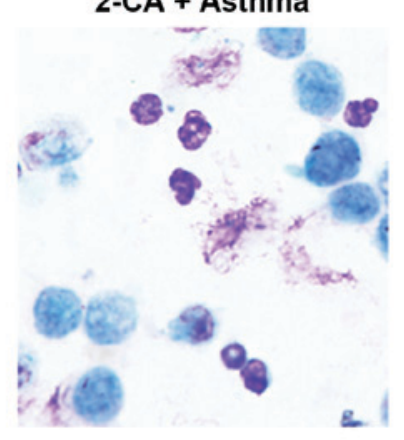

C

Lung tissue

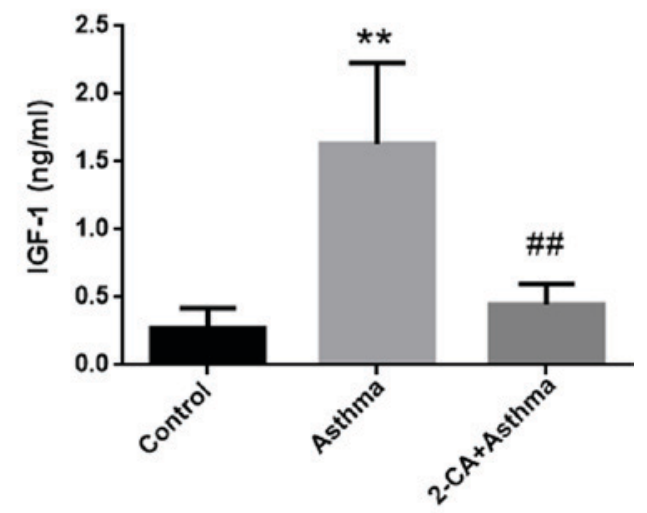

Figure 3. Treatment with 2-CA reduces the content of IGF-1 in the BALF and lung tissues of asthmatic mice. Cell acquisition via bronchoalveolar lavage was presented by (A) Wright staining, and the concentration of IGF-1 was determined in (B) BALF and (C) lung tissues of asthmatic mice with or without 2-CA treatment using ELISA. ${ }^{* *} \mathrm{P}<0.01$ vs. the control group; ${ }^{\# \#} \mathrm{P}<0.01$ vs. the asthma group. BALF, bronchoalveolar lavage fluid; IGF-1, insulin-like growth factor 1 ; 2-CA, 2-chloroadenosine.

hyperplasia (23). Another study also revealed that patients with ARDS at the early stage exhibited increased IGF-1 in BALF (24). The results of the present study demonstrated that the content of IGF-1 in lung tissue and BALF was significantly upregulated in mice with chronic asthma compared with the control group.

IGF-1 is produced in numerous types of cell, including endothelial cells, epithelial cells, macrophages, adipose-derived stem cells, nucleus pulposus cells and dental pulp stem cells (25-28). Recently, Wang et al (29) reported that epidermal $\mathrm{T}$ cells also produced IGF-1. The results of the present study suggested that IGF-1 may derive from AMs in the lungs of asthmatic mice. Fritz et al (30) revealed that mouse AMs produced IGF-1, which is consistent with the findings of the present study. IGF-1 can promote the proliferation and differentiation of various types of cell. Yu et al (31) reported that IGF-1 may promote the proliferation of myoblast cells and serves an important role in the growth of skeletal muscle. In addition, IGF-1 was involved in the differentiation of mesenchymal stem cells into neural progenitor-like cells by promoting the proliferation and inhibiting apoptosis (32). Weng et al (33) demonstrated that IGF-1 may induce the proliferation of human retinal pigment epithelial cells and was considered to be the mitotic origin of these cells. IGF-1 also stimulated the growth of tumor cells of lung, liver and breast cancer, as well as osteosarcoma (34-37). Narasaraju et al (9) reported that IGF-1 served an important role in the proliferation and differentiation of alveolar epithelial cells in rats. In

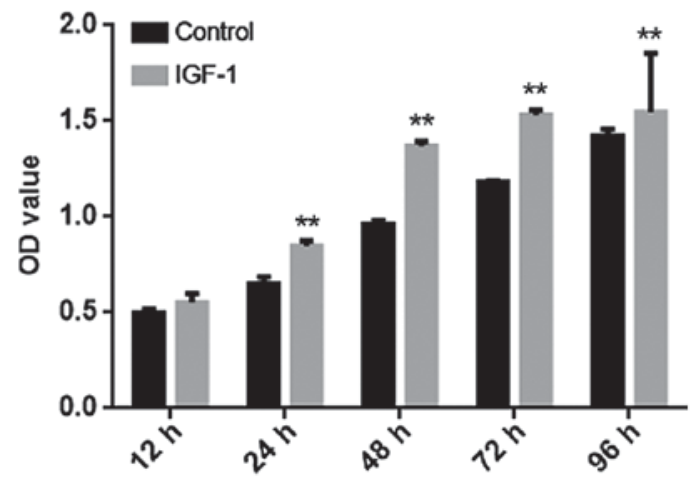

Figure 4. IGF-1 promotes the proliferation of alveolar epithelial cells. MLE-12 cells $\left(3 \times 10^{3}\right)$ were stimulated with IGF-1 $(10 \mathrm{ng} / \mathrm{ml})$ for $12,24,48,72$ and $96 \mathrm{~h}$, and cell proliferation was determined using a Cell Counting Kit-8 assay. ${ }^{* *} \mathrm{P}<0.01$ vs. the control group. IGF-1, insulin-like growth factor 1 ; OD, optical density.

the present study, IGF-1 promoted the proliferation of mouse AECs. As AMs and AECs are located adjacently in the alveolar microenvironment, IGF-1 derived from AMs may regulate pulmonary remodeling by affecting AECs.

IGF-1 signaling is involved in the inflammatory response (18). IGF-1 inhibits inflammatory responses by suppressing the release of inflammatory cytokines, including IL-1 $\beta$ and tumor necrosis factor- $\alpha$ (38). Alternatively, IGF-1 also stimulates the production of anti-inflammatory cytokines, including IL-4 and IL-10 to inhibit inflammatory 
A

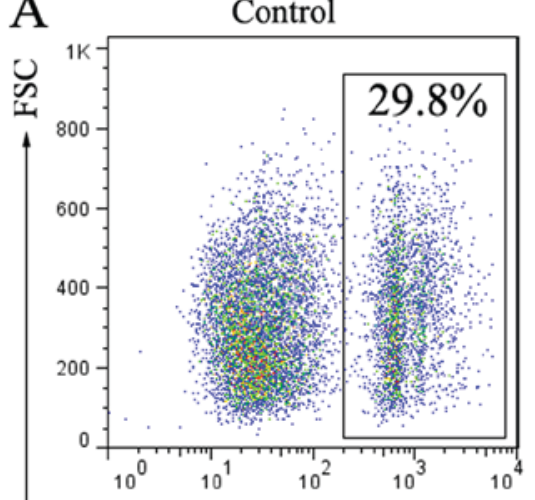

IGF-1

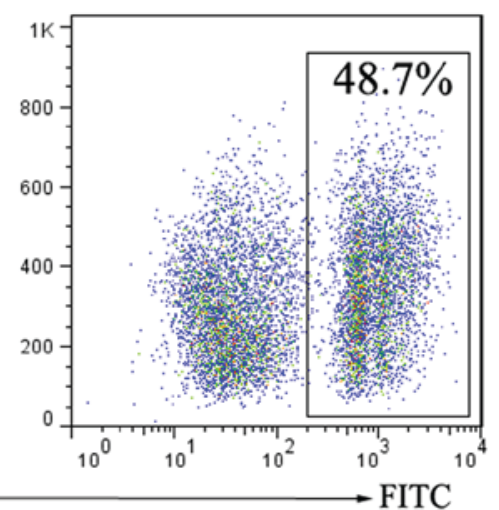

B

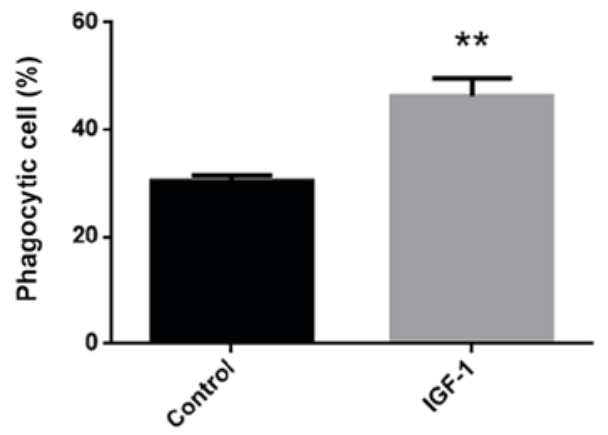

Figure 5. IGF-1 promotes the phagocytosis of alveolar epithelial cells. MLE-12 cells stimulated with IGF-1 (50 ng/ml) for $48 \mathrm{~h}$ were incubated with FITC-labeled microspheres for $2 \mathrm{~h}$. The percentage of FITC-positive cells was determined by flow cytometry. (A) Representative flow cytometry plots. (B) Statistical analysis of the results from flow cytometry. ${ }^{* *} \mathrm{P}<0.01$ vs. the control group. FSC, forward scatter; FITC, fluorescein isothiocyanate; IGF-1, insulin-like growth factor 1

responses (39). Additionally, the removal of endotoxins and apoptotic bodies is promoted by phagocytosis to inhibit the inflammatory response and maintain the balance of the internal environment (40). A recent study revealed that IGF-1 served an important role in inflammatory responses by promoting the phagocytosis of dendritic cells (41). The present study indicated that IGF-1 induced the phagocytosis of AECs, suggesting that IGF-1 may inhibit pulmonary inflammation by affecting the alveolar cells required for structure, consequently maintaining the balance of alveolar microenvironment.

In summary, the expression levels of IGF-1 were significantly increased in the lungs of asthmatic mice; elevated IGF-1 was predominantly originated from AMs. The results of the present study indicated that AM-derived IGF-1 may serve an important role in the regulation of airway inflammation and remodeling in asthmatic mice. Further studies should be conducted to identify the functions of IGF-1 and its downstream molecules in allergic airway inflammation, which may provide novel insight into the treatment of this disease.

\section{Acknowledgements}

Not applicable.

\section{Funding}

The present study was supported by the National Science Foundation of China (grant no. 81273273), Anhui Provincial Natural Science Foundation (grant no. 1708085MH218) and the Scientific Research Innovation Team Project of Anhui Colleges and Universities (grant no. 2016-40).

\section{Availability of data and materials}

All data generated or analyzed during this study are included in this article.

\section{Authors' contributions}

QF, SG and CS made substantial contributions to the design of the present study. JH, MM, HW, HM and XT performed the experiments. CS wrote the manuscript. All authors read and approved the manuscript.

\section{Ethics approval and consent to participate}

The present study was approved by the Ethics Committee of Bengbu Medical College (Bengbu, China).

\section{Patient consent for publication}

Not applicable.

\section{Competing interests}

The authors declare that they have no competing interests.

\section{References}

1. Thomson NC, Chaudhuri R and Spears M: Emerging therapies for severe asthma. BMC Med 9: 102, 2011.

2. Anandan C, Nurmatov U, van Schayck OC and Sheikh A: Is the prevalence of asthma declining? Systematic review of epidemiological studies. Allergy 65: 152-167, 2010.

3. Lu J, Xiong L, Zhang X, Liu Z, Wang S, Zhang C, Zheng J, Wang G, Zheng R, Simpson JL and Wang F: The role of lower airway dysbiosis in asthma: Dysbiosis and asthma. Mediat Inflamm 2017: 3890601, 2017.

4. Davies DE: The role of the epithelium in airway remodeling in asthma. Proc Am Thorac Soc 6: 678-682, 2009.

5. Orrù S, Nigro E, Mandola A, Alfieri A, Buono $\mathrm{P}$, Daniele $\mathrm{A}$ Mancini A and Imperlini E: A functional interplay between IGF-1 and adiponectin. Int J Mol Sci 18: E2145, 2017.

6. Mangiola A, Vigo V, Anile C, De Bonis P, Marziali G and Lofrese G: Role and importance of IGF-1 in traumatic brain injuries. Biomed Res Int 2015: 736104, 2015.

7. Maggio M, De Vita F, Lauretani F, Buttò V, Bondi G, Cattabiani C, Nouvenne A, Meschi T, Dall'Aglio E and Ceda GP: IGF-1, the cross road of the nutritional, inflammatory and hormonal pathways to frailty. Nutrients 5: 4184-4205, 2013.

8. Krein PM and Winston BW: Roles for insulin-like growth factor-I and transforming growth factor-beta in fibrotic lung disease. Chest 122: 289S-293S, 2002.

9. Narasaraju TA, Chen H, Weng T, Bhaskaran M, Jin N, Chen J, Chen Z, Chinoy MR and Liu L: Expression profile of IGF system during lung injury and recovery in rats exposed to hyperoxia: A possible role of IGF-1 in alveolar epithelial cell proliferation and differentiation. J Cell Biochem 97: 984-998, 2006. 
10. Warnken M, Reitzenstein U, Sommer A, Fuhrmann M, Mayer P, Enzmann H, Juergens UR and Racké K: Characterization of proliferative effects of insulin, insulin analogues and insulin-like growth factor-1 (IGF-1) in human lung fibroblasts. Naunyn Schmiedebergs Arch Pharmacol 382: 511-524, 2010.

11. Hung CF, Rohani MG, Lee SS, Chen P and Schnapp LM: Role of IGF-1 pathway in lung fibroblast activation. Respir Res 14: 102, 2013.

12. Chetty A and Nielsen HC: Regulation of cell proliferation by insulin-like growth factor-1 in hyperoxia-exposed neonatal rat lung. Mol Genet Metab 75: 265-275, 2002.

13. Vieira RP, Duarte AC, Claudino RC, Perini A, Santos AB, Moriya HT, Arantes-Costa FM, Martins MA, Carvalho CR and Dolhnikoff M: Creatine supplementation exacerbates allergic lung inflammation and airway remodeling in mice. Am J Respir Cell Mol Biol 37: 660-670, 2007.

14. Ma H, Wang H, Luo Y, Guo S and Song C. Mir-20b-induced increase in myeloid-derived suppressor cells in the lungs of mice with chronic Asthma. Ann Clin Lab Sci 47: 76-82, 2017.

15. Song C, Ma H, Yao C, Tao X and Gan H: Alveolar macrophage-derived vascular endothelial growth factor contributes to allergic airway inflammation in a mouse asthma model. Scand J Immunol 75: 599-605, 2012.

16. Song C, Yuan Y, Wang XM, Li D, Zhang GM, Huang B and Feng ZH: Passive transfer of tumour-derived MDSCs inhibits asthma-related airway inflammation. Scand J Immunol 79 : 98-104, 2014

17. Song C, Luo L, Lei Z, Li B, Liang Z, Liu G, Li D, Zhang G, Huang B and Feng ZH: IL-17-producing alveolar macrophages mediate allergic lung inflammation related to asthma J Immunol 181: 6117-6124, 2008.

18. Labandeira-Garcia JL, Costa-Besada MA, Labandeira CM, Villar-Cheda B and Rodríguez-Perez AI: Insulin-like growth factor-1 and neuroinflammation. Front Aging Neurosci 9: 365, 2017.

19. Serizier SB and McCall K: Scrambled eggs: Apoptotic cell clearance by non-professional phagocytes in the Drosophila ovary. Front Immunol 8: 1642, 2017.

20. Li S, Geng J, Xu X, Huang X, Leng D, Jiang D, Liang J, Wang C, Jiang D and Dai H: miR-130b-3p modulates epithelial-mesenchymal crosstalk in lung fibrosis by targeting IGF-1. PLoS One 11: e0150418, 2016.

21. Hamaguchi Y, Fujimoto M, Matsushita T, Hasegawa M, Takehara $\mathrm{K}$ and Sato $\mathrm{S}$ : Elevated serum insulin-like growth factor (IGF-1) and IGF binding protein-3 levels in patients with systemic sclerosis: Possible role in development of fibrosis. J Rheumatol 35: 2363-2371, 2008.

22. Maeda A, Hiyama K, Yamakido H, Ishioka $S$ and Yamakido $M$ : Increased expression of platelet-derived growth factor $\mathrm{A}$ and insulin-like growth factor-I in BAL cells during the development of bleomycin-induced pulmonary fibrosis in mice. Chest 109 : 780-786, 1996

23. Krein PM, Sabatini PJ, Tinmouth W, Green FH and Winston BW: Localization of insulin-like growth factor-I in lung tissues of patients with fibroproliferative acute respiratory distress syndrome. Am J Respir Crit Care Med 167: 83-90, 2003.

24. Schnapp LM, Donohoe S, Chen J, Sunde DA, Kelly PM, Ruzinski J, Martin T and Goodlett DR: Mining the acute respiratory distress syndrome proteome: Identification of the insulin-like growth factor (IGF)/IGF-binding protein-3 pathway in acute lung injury. Am J Pathol 169: 86-95, 2006.

25. Ahluwalia A, Jones MK, Hoa N and Tarnawski AS: NGF protects endothelial cells from indomethacin-induced injury through activation of mitochondria and upregulation of IGF-1. Cell Signal 40: 22-29, 2017.
26. Bagno LL, Carvalho D, Mesquita F, Louzada RA, Andrade B, Kasai-Brunswick TH, Lago VM, Suhet G, Cipitelli D, Werneck-de-Castro JP and Campos-de-Carvalho AC: Sustained IGF-1 secretion by adipose-derived stem cells improves infarcted heart function. Cell Transplant 25: 1609-1622, 2016.

27. Zhu Z, Huang P, Chong Y, George SK, Wen B, Han N, Liu Z, Kang L and Lin N: Nucleus pulposus cells derived IGF-1 and MCP-1 enhance osteoclastogenesis and vertebrae disruption in lumbar disc herniation. Int J Clin Exp Pathol 7: 8520-8531, 2014.

28. Magnucki G, Schenk U, Ahrens S, Navarrete Santos A, Gernhardt CR, Schaller HG and Hoang-Vu C: Expression of the IGF-1, IGFBP-3 and IGF-1 receptors in dental pulp stem cells and impacted third molars. J Oral Sci 55: 319-327, 2013.

29. Wang Y, Bai Y, Li Y, Liang G, Jiang Y, Liu Z, Liu M, Hao J, Zhang $\mathrm{X}, \mathrm{Hu} \mathrm{X}$, et al: Il-15 enhances activation and IGF-1 production of dendritic epidermal $\mathrm{T}$ cells to promote wound healing in diabetic mice. Front Immunol 8: 1557, 2017.

30. Fritz JM, Dwyer-Nield LD and Malkinson AM: Stimulation of neoplastic mouse lung cell proliferation by alveolar macrophage-derived, insulin-like growth factor-1 can be blocked by inhibiting MEK and PI3K activation. Mol Cancer 10: 76, 2011.

31. Yu M, Wang H, Xu Y, Yu D, Li D, Liu X and Du W: Insulin-like growth factor-1 (IGF-1) promotes myoblast proliferation and skeletal muscle growth of embryonic chickens via the PI3K/Akt signalling pathway. Cell Biol Int 39: 910-922, 2015.

32. Huat TJ, Khan AA, Pati S, Mustafa Z, Abdullah JM and Jaafar H: IGF-1 enhances cell proliferation and survival during early differentiation of mesenchymal stem cells to neural progenitor-like cells. BMC Neurosci 15: 91, 2014.

33. Weng CY, Kothary PC, Verkade AJ, Reed DM and Del Monte MA: MAP kinase pathway is involved in IGF-1-stimulated proliferation of human retinal pigment epithelial cells (hRPE). Curr Eye Res 34: 867-876, 2009.

34. Zhou Y, Li S, Li J, Wang D and Li Q: Effect of microRNA-135a on cell proliferation, migration, invasion, apoptosis and tumor angiogenesis through the IGF-1/PI3K/Akt signaling pathway in non-small cell lung cancer. Cell Physiol Biochem 42: 1431-1446, 2017.

35. Ma Y, Han CC, Li Y, Wang Y and Wei W: Insulin-like growth factor-binding protein-3 inhibits IGF-1-induced proliferation of human hepatocellular carcinoma cells by controlling bFGF and PDGF autocrine/paracrine loops. Biochem Biophys Res Commun 478: 964-969, 2016.

36. Sarkissyan S, Sarkissyan M, Wu Y, Cardenas J, Koeffler HP and Vadgama JV: IGF-1 regulates Cyr61 induced breast cancer cell proliferation and invasion. PLoS One 9: e103534, 2014.

37. Tan X, Fan S, Wu W and Zhang Y: MicroRNA-26a inhibits osteosarcoma cell proliferation by targeting IGF-1. Bone Res 3: 15033, 2015.

38. Puzik A, Rupp J, Tröger B, Göpel W, Herting E and Härtel C: Insulin-like growth factor-I regulates the neonatal immune response in infection and maturation by suppression of IFN- $\gamma$. Cytokine 60: 369-376, 2012.

39. O'Connor JC, McCusker RH, Strle K, Johnson RW, Dantzer R and Kelley KW: Regulation of IGF-I function by proinflammatory cytokines: At the interface of immunology and endocrinology. Cell Immunol 252: 91-110, 2008.

40. Gordon S: Phagocytosis: An immunobiologic process. Immunity 44: 463-475, 2016

41. Xuan NT, Hoang NH, Nhung VP, Duong NT, Ha NH and Hai NV: Regulation of dendritic cell function by insulin/IGF-1/PI3K/Akt signaling through klotho expression. J Recept Signal Transduct Res 37: 297-303, 2017. 